\title{
SOCIAL WORK OF THE CATHOLIC CHURCH IN AMERICA
}

\author{
By William J. Kerby,
}

Professor of Sociology, Catholic University of America, Washington, D. C.

The social work of the Catholic Church is so intimately bound up with its whole view of life and its normal service of souls that one cannot understand its spirit, agencies or motives unless they are studied in their organic relation to the processes of spiritual life fostered in the traditions of the Church. Doctrinally and historically social service is part of the soul's supernatural life; the development of spiritual emotions concerning one's fellowman is due largely to teaching and practice concerning social service, which have been in the foreground in the life of the Church. Hence, any objective description must take beginning in the estimate of social service to be found in the Catholic view of life. In the exposition here offered, attention is confined to the Church in United States.

By social work may be understood service of the weak by the strong. Whether the relation be direct or indirect, the aim is one-to sustain the helpless weak, to strengthen the hopeless weak, to protect the defenseless weak, and to prevent weakness when possible, making the individual self-sufficient, in advance of falling victim to circumstances which rob him of strength and outlook. Whether weakness is in the individual or in the mass; whether culpable or blameless; whether due to calamity, accident or the merciless evolution of industry, it does not affect the claim of the weak or the motive of the strong in giving aid. The Church is vividly conscious of natural and supernatural solidarity in the race; she accepts Christ's teaching on the dignity and merit of social service, seeing in it an essential section in the supreme law of love. Whatever changes social development may bring into the details of social weakness, the spirit and motive of the Church's relation to it remain unchanged, though, naturally, methods will vary with time and place. In the mind of the Church, then, social service is supernatural in character, motive and result. It is an organic part of religious activity, of the process of individual sanctification. 
The service is conceived as distinct from the merit of the recipient, though the wisest traditions of practice impose effective and discriminating restraints on giving. Service must be personal in the most complete sense if it is to be spiritual. It is co-ordinated with prayer and fasting as a highly meritorious supernatural action, as a traditional form of expiation for sin and one of the noblest proofs of consecration to God. Thus, in the Society of St. Vincent de Paul, a highly efficient and progressive lay association devoted to social work, personal social service, is formally represented as a great factor in the work of personal sanctification.

Throughout the history of the Church there have been occasions when some pressing social problem called for relief and personal service. In response to such demands, men and women of intense spirituality and wide-looking charity have felt called on to meet the situation by organizing like-minded persons into religious communities for such service. The members release themselves from basic human attachments by vows and give themselves up to the service of God in social work. Thus the noble estimate of social service found in the Church is met by an equally noble form of personal consecration to it, and in consequence the religious community has been the distinctive agent of social work through the centuries. Once the religious community is organized, approved and active, it becomes a permanent center of religious consciousness, an organ of the spiritualized social conscience and a ready agent for action, its numbers increasing as demands for service multiply.

In the development of the Church the diocese is the unit of organization and growth; the bishop is the leader, organizer, ruler of spiritual life. The diocese is conscious, therefore, of a definite spiritual duty to meet problems of weakness within its limits. The traditions of the Church make the bishop responsible, as far as his circumstances will allow, for the aged poor, the sick poor, the orphans, the fallen. Hence institutions to meet these problems belong to the usual integrity of diocesan equipment. The bishop calls to his aid religious communities, which assume charge of the greater social works undertaken, and appoints, when conditions warrant it, an official diocesan director of charities.

The parish is the unit within the diocese. Its sense of social and spiritual solidarity creates an impulse toward relief of lesser 
social problems which touch those who are associated around a common center of worship. Under the direction of the priest, clubs, sodalities, societies arise, one of whose aims is to relieve those who, in any way, are in need.

The development of the city with its distinctive and complex social problems appears to affect somewhat the direction of social conscience. The Catholics of a city tend toward a common sense of relation to problems, since these are city and not parish problems. Hence a tendency, particularly in lay Catholic activity, toward formation of associations which aim to meet common conditions in the city.

Thus the religious community, the diocese, the parish, the city are definite centers of social consciousness which expresses itself in organization for service. Although the religious communities command greatest attention in their social work, lay activity is extensive, sustained and efficient. Religious communities of either men or women, such as now under consideration, may be divided into three classes: $(a)$ those which are devoted exclusively to social service, as caring for the aged poor, for fallen women, for the sick poor in their homes; $(b)$ those engaged in many kinds of work, including social work, as teaching communities, which also conduct hospitals, orphanages, etc.; (c) those whose main work is other than social, but which incidentally and in relation to their chief work do much in social service, as teaching sisters who visit the sick poor and distribute outdoor relief. Lay associations for purposes of social service may be classified in the same way.

Social problems in the last analysis are reduced to terms of the individual; social reform must bear in mind the re-establishment of individuals. Causes of weakness in the individual are more often social than personal. Social work, therefore, may aim to relieve. console and reconstruct individuals, or it may be directed toward general causes. Thus we have relief and prevention, individual and social reconstruction. It may be said, on the whole, that the Church's social work is directed more towards effects than toward causes; toward personal action on the individual rather than on social forces; toward the spiritual more than the temporal. The Church is quick and tender in caring for the aged poor, yet she is not conspicuous in demanding old age pensions; she is watchful of the morals of children and tireless in instructing them, yet 
not in advance in dealing specifically with tenement problems; she is sleepless in caring for orphans, yet not particularly aggressive in compelling employers to cover dangerous machinery or in asking society to make stringent laws concerning occupations harmful to health; she is first and strongest in defending the sanctity of the home, yet not remarkable for works in favor of sanitary housing.

Nor is this strange. It may be that the Church is somewhat under the influence of traditions which saw in individuals whole spiritual individuals and not merely social forces. The individual and not the social force is the unit on which in the main she works. In a time when the individual is strong and conscience is uppermost, religion can, in its own right, do much. But the complex organization of society has placed social forces and conditions in the ascendency and has secularized the agents which deal with them. Nowadays we aim to reform by law and public opinion. Causes of social ills are said to be secular and social; religion is made a matter of private concern; law is a matter of politics, and it is preferred that the Church keep out of politics. While religion is welcomed as an ally in acting on public opinion, and churchmen do so act with power, the tendency is growing by force of circumstances to restrict the Church to action of a secondary kind, and to leave to secular power, leadership in reform work. This is the more marked since religions still divide men while their social interests are identical. This action of the Church on victims of social conditions is supplemented by her normal teaching of duty and spiritual truth, and she hopes always that, if her organic teaching be but accepted, she will include, in the beneficent results which follow, all that may be looked for from law.

However, one spirit and aim stand out strongly in all her social work-the maintenance of the family in its integrity. Her normal teaching holds families together when nothing else could, and her agents of reform exhaust every resource before they permit the breaking of the family bond and consequent disintegration.

Although the estimate and inspiration of social work are Catholic and supernatural, on the whole there is found in the work a breadth which extends service far beyond the limits of catholicism. In many of our institutions, if memory be not at fault, no question is permitted concerning the religion of one entering to obtain relief, and no discrimination is made because of religion. 
An important asset in the social work of the Church is found in the quick and effective co-ordination among the agents of service by which acute situations may be readily met. The priest is in constant touch with the people in sick calls, visitation, census taking and in answer to appeals. The people of every unfortunate class, as well as others, come to the church for sacraments, for obligatory worship. In distress the Catholic's first instinct is to turn toward his Church. Catholic children are brought to the Catholic school. Teacher and pupil are in personal and confidential relation. In this way information is quickly brought out concerning distress or need, and at once agents are at hand for action. This, together with the formal activity of lay and religious associations, makes possible very efficient service. Naturally, in spite of this, many cases escape notice, but the substantial results of co-operation are large.

As this co-ordination is an important factor in the Church's equipment, an illustration well known to the writer may be cited: A lay organization, the St. Vincent de Paul Society, took the initiative in founding a summer home for poor children near Baltimore. It is one of a number already begun by the society. A teaching community of priests, the Sulpitians, placed fifty acres of woodland, with fine buildings, at the disposal of the society. Sisters of Charity conducted the home for the first summer, Sisters of Mercy for the second, in 1907. Bands of 125 children from the poorest sections of the city are chosen and collected by laymen and brought to the home for a twelve-day visit. All acute cases of illness occurring are cared for at a nearby hospital conducted by Sisters of Charity, sisters, physicians and nurses giving services gladly. All chronic cases of any kind and defects in senses, etc., discovered while the children are at the home are taken up after the children leave and treated to successful issue in the City Hospital, conducted by Sisters of Mercy. Some twenty Catholic organi.zations in the city, the clergy and numbers of laymen to whom the work appeals, contribute generously. Practically no expense is incurred in administration and management of the home, so that the maximum return in social service is had on funds contributed. Cases of distress or want in homes of the children which come to the notice of the administration are taken up at once by the St Vincent de Paul Society. Over seven hundred children are received during one season, each child having twelve days' outing. The 
home works admirably and with splendid results, but it could not do so were any of the agencies mentioned not at the generous service of the others, without hesitation and practically without expense.

The fundamental problem in social work is the family. There are agencies of relief at hand to serve it and its members. Many societies, both religious and lay, seek out and visit the homes of the poor, nurse the sick, instruct and stimulate all who have need of such aid. Religious communities of all kinds do immense service in distributing outdoor relief and bearing personal ministration to the home, likewise lay associations, chief among which is the St. Vincent de Paul Society. Its rule tells us "No work of charity is foreign to the society, although its special object is to visit poor families." Whatever the agent which acts, hospitals, orphan asylums, homes of preservation are at command when any of them are needed to meet an emergency. Through action of both religious and lay associations, neighborhood classes are formed for cooking, sewing, basket-work and other pursuits much after the manner of settlement work. Day nurseries care for children of mothers who work; summer homes provide outings for children of poor homes; associations provide outfits for newly born infants and offer Christmas joys to the children who otherwise would never know of Santa Claus save as a dream. Employment bureaus are operated in connection with many associations; sometimes we find successful endeavors to provide temporary loans or carry a longstanding insurance policy which otherwise would be lost. In larger cities, homes for destitute children, newsboys, homeless boys are found.

In the main, orphans are cared for in asylums conducted by sisters. Effort is usually made to place the children early in care-fully selected homes. Some difficulties are met when state laws shut out childran born outside of the state. In many cases industrial schools succeed the orphan asylum, and boys and girls are brought to a condition of independence under institutional care.

Fallen women, either legally committed or voluntarily seeking reformation, are cared for in Good Shepherd or Magdalen homes conducted by sisters. In their work provision is made for every class of inmate. Those who are completely won and desire to remain secluded from the world, form a class by themselves and live a life in retirement, labor and prayer. Children whose morals 
are in danger are taken into preservation classes and receive schooling and industrial training.

Insane, feeble-minded, deaf and dumb are cared for by sisters in institutions. Homes for working girls are instituted to give the inmates the security of home and the refinement of association that may protect them.

The sick poor are cared for in their homes or in hospitals. In this connection hospitals are peculiarly organized. Some are entirely for the poor, for indigent consumptives, for cripples, incurables, all conducted by sisters or brothers. The majority of hospitals, however, aim to serve the well-to-do as much as the poor. But, on the whole, through revenues received from the former, the institution and its staff of nurses and physicians of every form of faith, and Catholic sisters are enabled to maintain quarters and give services to the helpless poor, both in the hospital and through widely developed free dispensary work. In many instances maternity hospitals are found where unfortunate mothers may find refuge and their infants are saved from the dangers which usually threaten them.

Work among the colored people and the Indians is extensive. It is to a great extent similar in spirit and scope to the general social work of the Church. Much is done with varying but increasingly hopeful results in the cause of temperance. Parish organizations are found in great numbers, children are pledged on occasion of first communion or confirmation to total abstinence; schools, colleges, academies have active temperance societies. Usually appeal is made to the supernatural, and the thought of the Sacred Thirst of our divine Saviour is appealed to to strengthen children against drink. Local and diocesan organizations are united in one great national movement, the Catholic Total Abstinence Union, which works close to the spirit of the American hierarchy. One thousand and thirty-eight societies are federated in the union.

As on the whole the character and work of religious communities is fairly well understood by those who desire to know of them, no details of organization are now offered. Since no directory of lay social service exists, it is quite impossible to offer any detailed information concerning methods or extent of activity, nor can numbers in societies of men and of women be stated with any accuracy. Societies, based on the bond of nationality or locality, and founded for purposes of mutual benefit, insurance and the like, 
incorporate many forms of social service for members, and contribute in marked ways to funds which enable religious communities to accomplish so much. Such organizations are numerous and efficient among those of Irish and of German descent in this country. Within their own circles and beyond them, they show large results in works of relief and prevention.

The St. Vincent de Paul Society is the greatest lay association in the Church devoted, strictly from a general spiritual standpoint, to social service. The unit of organization is the conference in the parish, which meets weekly. The conferences of a city are united into a particular council, which expresses the mind of the society in the city, holds quarterly meetings and provides for general situations and special problems. The particular council usually creates the special works committee which has large powers in dealing with questions. Over the particular council stands the central or superior council, which takes in a section, a diocese or a country. The council general is the highest authority.

Members are naturally those who feel drawn to social work. The chief aim is to visit poor families, defend and maintain them, procure employment for idle fathers and meet with energy and resources all demands for help. The society works always in close relation with priest, bishop and religious community, and has the whole range of institutions in the church back of it in its work. Its constitution and rules permit great elasticity. In New York the society conducts a home for convalescent women, a summer home for poor children, a home bureau for placing out orphans in homes and keeping record of their welfare. It maintains special committees for visiting the poor in hospitals, the Juvenile Court prisoners, for conducting boys' clubs and an employment bureau. In other large cities its work is equally varied and more or less of the same nature.

Modern circumstances have so affected the weak and afflicted, and have so emphasized the material and social aspects of their condition, and civil and social authorities have become so active in positive relief work, that the question of relations among agents of social service becomes one of some importance. The idea of association is developing. Effort is made to co-ordinate all agents of social service in harmony, to prevent fraud and insure best results. From the foregoing exposition the reader may infer that 
varying attitudes toward co-operation would be found among Catholics. But the tendency is toward sympathetic exchange of services and recognition of the value of them to all active agents of charity. The International Convention of the St. Vincent de Paul Society, held in St. Louis in 1904, adopted a resolution to the effect that "As American citizens it is our duty to co-operate with charity workers of all creeds in all that pertains to the elevation of our fellow-beings, but in this co-operation we should be always guided by our rules, which wisely forbid the exposture of the misfortune of our poor." In large cities known to the writer, where co-operation with associated charities has been instituted, most encouraging results have bean secured. Participation by Catholics in the work of the National Conference of Charities and Corrections has not been without good results.

No records are available showing the range of social service given by lay associations of men and of women. The aggregate is surely imposing. There is on the whole a marked tendency in all charitable endeavor to be mindful of the feelings of the poor, even to the extent of guarding carefully names and amounts given in relief. Thus, in the St. Vincent de Paul Society, some officers have power to receipt for money used in relief and to keep secret the names of those aided. When an effort was made to install an exhibit of Catholic charities at the St. Louis Exposition, although it had highest approval from nearly the whole hierarchy, some opposition was met because merely of an instinctive dislike of any kind of publicity in social work. As a result, only an incomplete exhibit was made, and it was possible to include in it the work of only few lay associations.

It is impracticable at present to attempt to make any accurate statement concerning statistics of religious communities engaged in social work. The official Catholic Directory contains the greatest amount of material available. But some institutions present many features of activity among which distinction is not made in reporting. Thus an orphan asylum or a home for the aged conducted in connection with a Mother House will not show the number of sisters in active social work; in the directory poor patients are not distinguished from pay patients in hospitals; some hospitals report average numbers, while others report whole numbers for a year; some institutions fail to report the number of sisters engaged, 
others report them, but not the number of inmates. The works on the whole are so vast that any attempt at an analysis based on the full reports of the institutions themselves would go far beyond the scope of this paper.

On the whole, the traditions of social work in the Catholic Church are marked by a constant desire to let good works be known to God alone. The work is done as a form of consecration to God. It then has the right to be hidden from publicity. Those who have given their lives in this way to service of the weak and sorrowing are slow to welcome and reluctant to understand the publicity which nowadays accompanies social work. A religious community which sent many sisters as nurses in the Spanish war was unwilling to furnish any figures to an inquirer. The superior of a community devoted to nursing the sick in their homes kept no records which would enable a student to find the volume of work done. This spirit is so fixed and consistent that no effort is made in this exposition to present any tables of facts. A few were prepared at some expense of time and thought, but they were so far short of conveying a just impression of the social work of the Church on the whole, that it seemed best to omit them. An inquirer will not understand this work unless he look at it from the standpoint which places it in its relations to the whole Catholic spiritual estimate of life. When so studied, it is easily seen that much importance is attached to the desire not to let one hand know what the other gives. 